The Bangladesh Veterinarian (2013) 30(1) : 10 - 19

\title{
Construct and validation of progesterone-responsive luciferase reporter plasmid to detect progestogenic and anti-progestogenic activity
}

\author{
Ahmed $\mathrm{HMM}^{\star}$, Cheng WTK and Ou BR \\ Department of Animal Science and Biotechnology, Tunghai University, 181 Taichung \\ Harbor Road, Section 3, Taichung 40704, Taiwan
}

\begin{abstract}
Chemical and immunological analyses used to detect progesterone and its agonists and antagonists are unable to detect biological activities of unknown compounds. The objective of the experiment was to develop a progesterone-responsive reporter plasmid to detect progestogens and anti-progestogens. Progesterone-responsive luciferase reporter plasmid, pGL3-2PRE-TATA, was constructed by inserting two progesterone-response elements (PRE) and the TATA box at the multiple cloning site of pGL3 basic vector. T47D human breast cancer cells were co-transfected with c pGL3-2PRE-TATA and pCH110 plasmid. The transfected cells were exposed to progesterone, anti-progesterone, herb extracts or animal serum to induce the luciferase gene expression. Cells were lysed, and cell lysates were used to measure the luciferase and $\beta$-galactosidase expression level as well as total protein content. Luciferase activity was normalized by $\beta$-galactosidase activity and total protein content. The constructed plasmid was sensitive to progestogens and anti-progestogens in a dose-responsive manner. The pGL3-2PRE-TATA plasmid can be used to detect the progestogenic and anti-progestogenic activity of known and unknown compounds. (Bangl. vet. 2013. Vol. 30, No. 1, 10 - 19)
\end{abstract}

\section{Introduction}

Progesterone is a steroid hormone involved in the establishment and maintenance of pregnancy (Graham and Clarke, 1997; Lessey, 2003) the reproductive cycle and mammary gland development (Lydon et al., 1995; Aupperlee et al., 2005). Progesterone also has functional roles in repair of myelin, regeneration of axon and neuroprotection (Schumacher et al., 2012). Sources of progesterone are ovaries (after ovulation), adrenal gland and placenta. Progesterone levels are lower in men and postmenopausal women than cyclic women (NIH, 2011) and gradually increase during pregnancy. Synthetic progestogens exert similar effects to progesterone, although their chemical structure, efficiency and pharmacokinetic properties differ (Stanczyk, 2003; Sitruk-Ware, 2004). Animal, plant (Iino et al., 2007) and synthetics are the three sources of progestogen. Some steroid hormones, chemicals and environmental wastes have progestogenic or anti-progestogenic activity (Chatterjee $e t$ al., 2008). Progestogens are widely used in hormone replacement therapy, contraception, treatment of cancer and of reproductive disorders, such as endometriosis and uterine adenomyosis (Spitz and Chwalisz, 2000; Kuhl and

*Corresponding author:- E-mail: manir.astec@yahoo.com 
Wiegratz, 2004; Jaakkola et al., 2011). Anti-progesterone (Mifepristone, RU486) blocks progesterone, and can be used for termination of early pregnancy (Hazra and Pore, 2001).

Progesterone exerts its effect on target tissue through genomic or non-genomic pathway (Baldi et al., 2009). In genomic pathway, progesterone exerts its effect through intracellular receptors (Lydon et al., 1995; Baldi et al., 2009), which binds to progesterone-response elements in regulatory regions of specific genes (Beato, 1989; Smith \& O'Malley 2004). In non-genomic pathway, progesterone alters the level of second messenger (Baldi et al., 2009) via membrane-bound progesterone receptor (Luconi et al., 1998 and Jang and Yi, 2005). Intracellular progesterone receptors express as isoforms PR-A and PR-B. Both are transcribed from a single gene by two distinct promoters and two translation initiation signals (AUG) (Mulac-Jericevic et. al, 2003). PR-B contains an additional $\mathrm{NH}_{2}$-terminal stretch of about 165 amino acids. The transactivating ability of PR-A is less strong than PR-B, and PR-A is a transcriptional suppressor (Schoonen et al., 1998).

Steroid-like synthetic chemicals are used as animal growth promoters (Ismail et al., 1995; Badr et al., 2010), plant growth enhancers (Uthairatanakij, 2007) pesticides and herbicides (Andersen et al., 2002). Heavy metallic and biochemical substances are used in plastic, leather and pharmaceutical industry (Osinubi and Saalu, 2009). Some chemicals affect the reproductive system of wildlife and humans (Vos et al., 2000; Sharpe, 2001) by inhibiting the steroid hormone from binding to its receptor (Hotchkiss et al., 2009).

Several assays have been developed to measure progesterone and anti-progesterone activities. The McPhail assay (McPhail, 1934) is a good in vivo assay to evaluate progesterone-induced effects on rabbit endometrium, but needs live animals. Enzyme-linked immunosorbent assay (ELISA) and radio-immuno assay (RIA) are commonly used, but are not able to detect biological activities of unknown compounds. Therefore, it is necessary to develop a new assay to detect the total progestogenic or anti-progestogenic activity of compounds. The objective of the study was to develop a progesterone-responsive luciferase reporter plasmid to detect progesterone and its agonists and antagonists.

\section{Material and Methods}

DNA vectors, chemicals and reagents

The pGL3 basic and pSV- $\beta$-galactosidase control vector, luciferase enzyme assay system, $\beta$-galactosidase enzyme assay system and restriction enzymes were purchased from Promega (Madison, WI, USA). Progesterone, oestradiol-17 $\beta$, testosterone, dexamethasone, melengesterone acetate (MGA), altrenogest and mifepristone (RU486) were bought from Sigma Aldrich (St. Louis, MO, USA). Lipofectamine 2000, Dulbecco's Modified Eagle Medium (DMEM) and fetal bovine serum (FBS) were purchased from Invitrogen (Carlsbad, CA, USA). 
Construction of reporter plasmid $p$ GL3-2PRE-TATA

The reporter plasmid pGL3-2PRE-TATA was constructed in two steps. First, two 104mer oligomers, antisense to each other, were synthesized by incorporating a minimal promoter, two progesterone-response elements upstream of the promoter, and HindIII restriction site at both ends. These oligomers were annealed by gradually reducing the temperature from $99^{\circ} \mathrm{C}$ to $25^{\circ} \mathrm{C}$ to synthesize a double-stranded DNA. In the second step, 86-bp DNA fragment was inserted into the HindIII restriction site of pGL3 basic vector to construct the recombinant plasmid, pGL3-2PRE-TATA (Fig. 1).

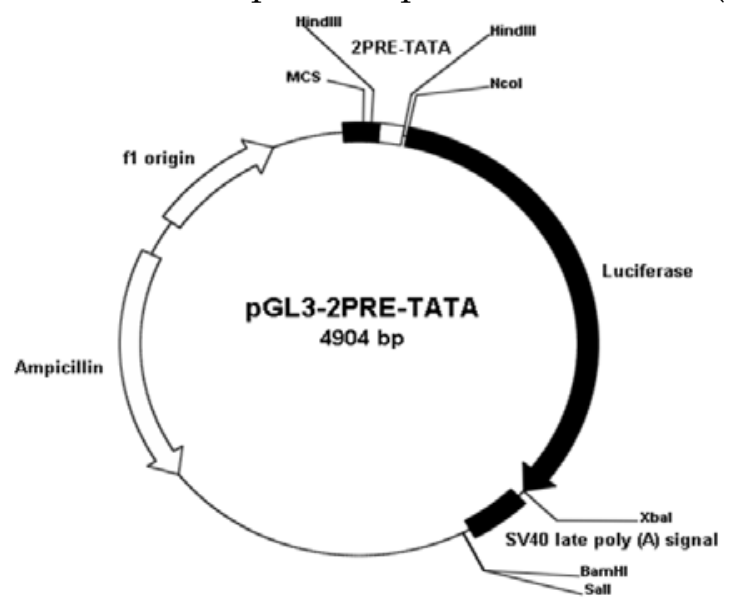

Fig. 1. Diagram of the constructed pGL3-2PRE-TATA plasmid. Two progesterone-response elements (PRE) and the TATA box were inserted at the multiple cloning site of pGL3 basic vector

\section{Cell culture}

Human breast adenocarcinoma cell line, T-47D, was purchased from the American Type Culture Collection (Manassas, VA, USA). Cells were cultured in DMEM supplemented with $1 \%$ sodium pyruvate, $3.7 \mathrm{~g} / \mathrm{L}$ sodium bicarbonate, and $10 \%$ FBS. For assay, cells were maintained in a phenol red-free DMEM supplemented with $1 \%$ sodium pyruvate and 10\% dextran-coated charcoal absorbed FBS or 10\% castrated pig serum. All cells were cultured at $37^{\circ} \mathrm{C}$ and $5 \% \mathrm{CO}_{2}$ in a humidified incubator.

\section{Cell transfection and progestogenic activity assay}

Two days before transfection, T47D cells were plated at $2.5 \times 10^{5}$ cells per well into six well plates with DMEM containing $2 \%$ dextran-coated charcoal FBS and incubated for 48 hours. Cells were co-transfected with $2 \mu \mathrm{g}$ of pGL3-2PRE-TATA and $1 \mu \mathrm{g}$ of pSV- $\beta$ galactosidase control vector using lipofectamine 2000, according to manufacturer's protocol. The transfected cells were treated with different concentrations of progesterone, anti-progesterone, other steroids, LC extract or $10 \%$ pig's serum. After 24 hours, cells were lysed and the cell lysates were used to determine luciferase and $\beta$ galactosidase activities by $\beta$-galactosidase and luciferase assay kits according to the manufacturer's instructions. Protein contents were determined by Bradford protein assay kit (Bio-Rad, Hercules, CA, USA). Luciferase activity was normalized by $\beta$-galactosidase activity and protein content. 


\section{Preparation of Ligusticum chuanxiong extracts}

Rhizome Ligusticum chuanxiong (LC) roots, purchased from Sun Ten Pharmaceutical Co. Ltd. (Taichung, Taiwan), were ground and soaked with 100\% ethanol for 72 hours at room temperature. The extracts were filtered and kept inside a hood for rapid evaporation of ethanol. Dried extracts were diluted at the stock concentration and kept at $-80^{\circ} \mathrm{C}$.

\section{Animal experiment design}

Four barrows Landrace-Duroc $\times$ Yorkshire with an average age of 6 to 8 months and average bodyweight of $120 \mathrm{~kg}$ were housed separately. Control was fed normal commercial feed, positive control supplemented with $20 \mathrm{mg}$ altrenogest and treatment pig supplemented with $100 \mathrm{~g}$ ethanolic extract of LC. Blood was collected from jugular vein before and after feeding. Samples were allowed to clot on ice and centrifuged at $1500 \times \mathrm{g}$ for 30 minutes at $4^{\circ} \mathrm{C}$ and kept at $-20^{\circ} \mathrm{C}$.

\section{Data analysis}

Luciferase activity in each well was measured as relative light units (RLU). All data were summarized from at least three independent experiments with triplicates. Fold induction was calculated by dividing the mean luciferase activity from different treatments (progesterone, anti-progesterone, other hormones, hormone-like substances, herbal extracts, and pig serum) with control wells. Data were analyzed by using Statgraphics software (STATGRAPHICS Centurion XVI, Warrenton, VA, USA). Each value is presented as the mean \pm SEM. Mean values were compared by analysis of variance (ANOVA) with LSD tests for comparing group. A significant level of 0.05 was adopted.

\section{Results and Discussion}

Response to progesterone and its agonist and antagonist

Plasmid pGL3-2PRE-TATA was highly sensitive to progesterone in a dose-dependent manner (Fig. 2). The minimal and maximal luciferase activities were found when cells were exposed to $1 \mathrm{nM}$ and $1 \mu \mathrm{M}$ of progesterone, respectively (Fig. 2). The maximal induced luciferase activity was 19.7 times that in vehicle control (Fig. 2). The minimal detectable luciferase activity was 1.98 times that in vehicle control (Fig. 2). There was no difference between more than $1 \mu \mathrm{M}$ and $1 \mu \mathrm{M}$ progesterone-induced luciferase activities. The induced luciferase activities of $1 \mu \mathrm{M}$ MGA and altrenogest were 18 and 17 times that in vehicle control, respectively (Fig. 3) but not significantly different from that induced by $1 \mu \mathrm{M}$ progesterone. To validate sensitivity to progesterone receptor antagonist, transfected cells were exposed to $100 \mathrm{nM}$ RU486 in presence of $100 \mathrm{nM}$ progesterone. Fig. 4 demonstrates that RU486 blocked the progesterone. 


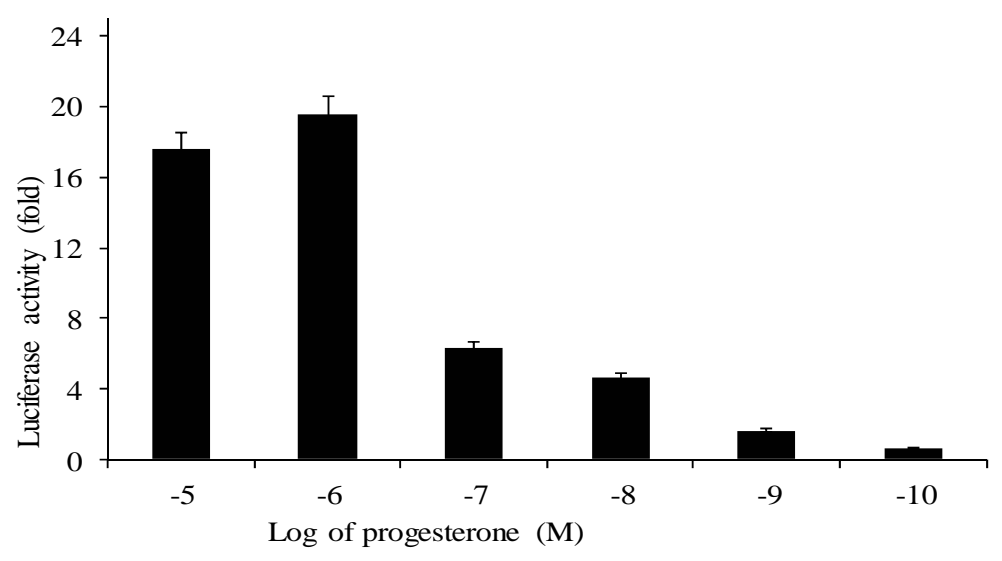

Fig. 2. Dose-dependent response of constructed plasmid to progesterone. Data represented as the mean fold induction compared to vehicle control \pm SEM

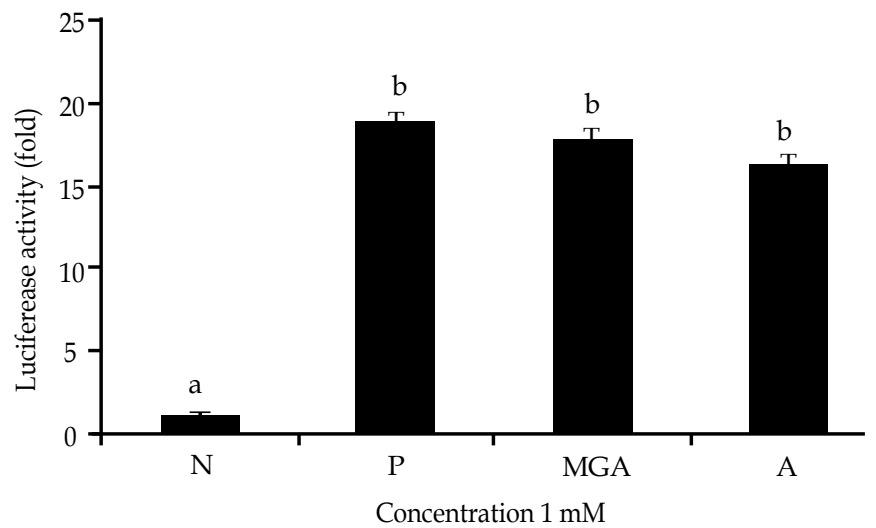

Fig. 3. Response to progesterone agonist of the constructed plasmid, negative control (N), progesterone (P) melengesterone acetate (MGA) and altrenogest (A). Data represented as the mean fold induction compared to vehicle control \pm SEM. Different letters denote significant difference $(\mathrm{P}<0.05)$

\section{Ligand specificity}

To investigate the ligand specificity of the recombinant plasmid pGL3-2PRE-TATA, transfected cells were exposed to oestrogen, testosterone, and dexamethasone. Concurrently cells were exposed to progesterone and ethanol as positive and vehicle control, respectively. Fig. 5 shows that $100 \mathrm{nM}$ oestrogen, testosterone, and dexamethasone failed to induce the luciferase activity compared to vehicle control.

\section{Response to LC extract}

LC extract from 20 to $40 \mu \mathrm{g}$ induced a dose-response increase in luciferase activity. LC extract $50 \mu \mathrm{g}$ or above induced a dose-responsive decrease in luciferase activity. At maximal concentration of $40 \mu \mathrm{g}$ LC extract, luciferase activity was 7 times that in vehicle control and was equivalent to $100 \mathrm{nM}$ progesterone-induced activity (Fig.s 2 and 6). 


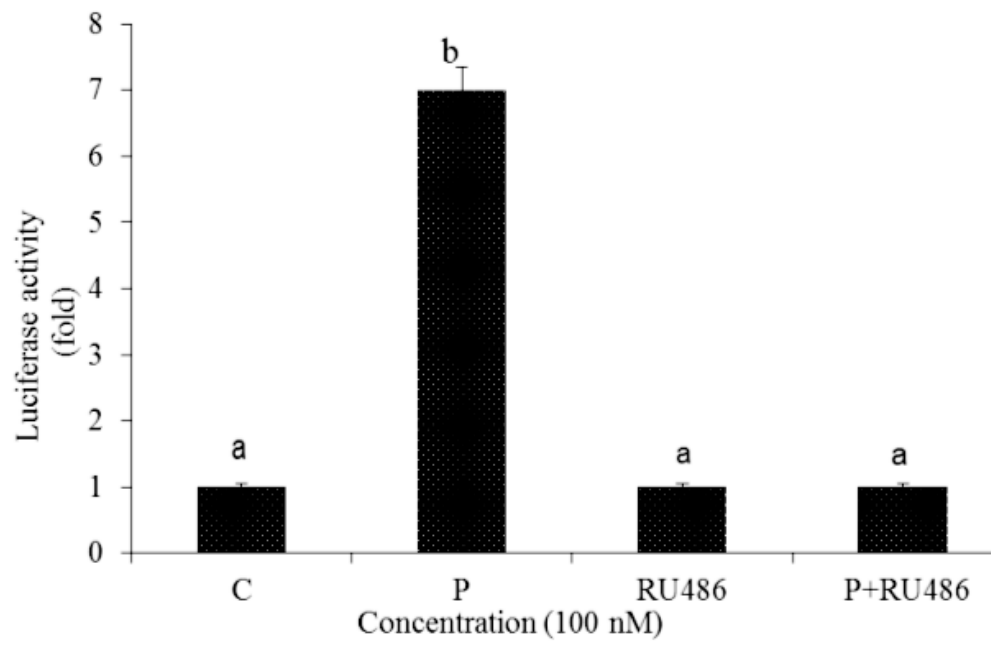

Fig. 4. Response to anti-progesterone (RU486), Control (C) and Progesterone (P). Data represented as the mean fold induction compared to vehicle control \pm SEM. Different letters denote significant difference $(\mathrm{P}<0.05)$

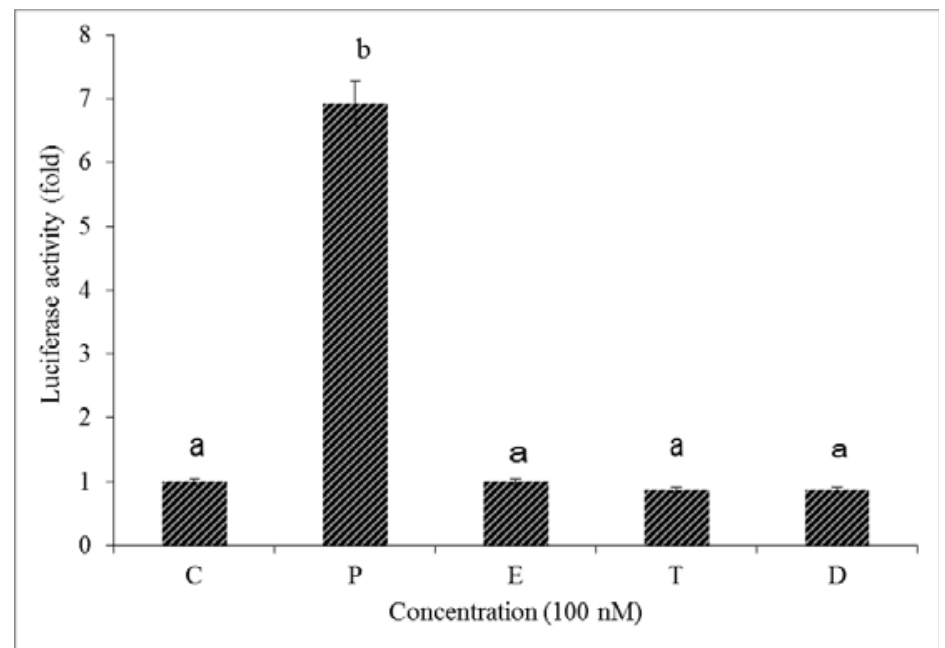

Fig. 5. Ligand specificity of the constructed plasmid, Control (C), Progesterone (P), Oestrogen (E), Testosterone $(\mathrm{T})$, and Dexamethasone (D). Data represented as the mean fold induction compared to vehicle control \pm SEM. Different letters denote significant difference $(\mathrm{P}<0.05)$

\section{Response to animal serum}

Castration of pigs largely eliminate endogenous source of progesterone. To validate the response to serum progesterone, castrated pigs were fed progestogen (altrenogest) and phytoprogesterone containing herb extract (LC) and serum was separated after collecting blood. Transfected cells were incubated for 24 hours with $10 \%$ pig sera. Fig. 7 shows that progestogenic activities of serum from LC extract-fed and altrenogest-fed animal were higher than control. Therefore, the constructed plasmid was sensitive to animal serum progestogen. 


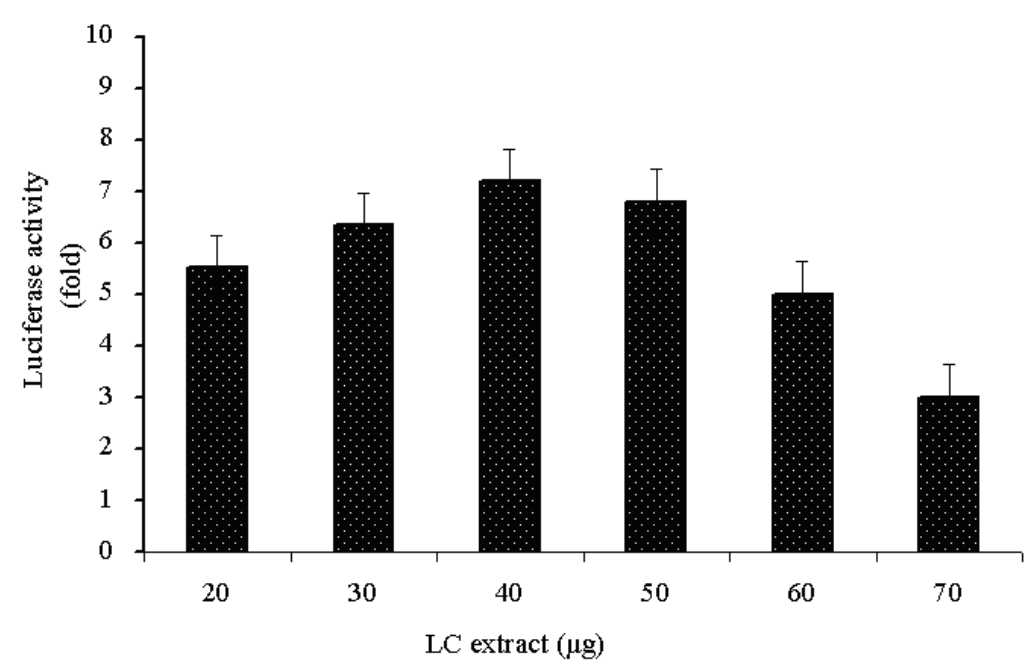

Fig. 6. Dose-dependent progestogenic activity of LC extract. Data represented as the mean fold induction compared to vehicle control \pm SEM.

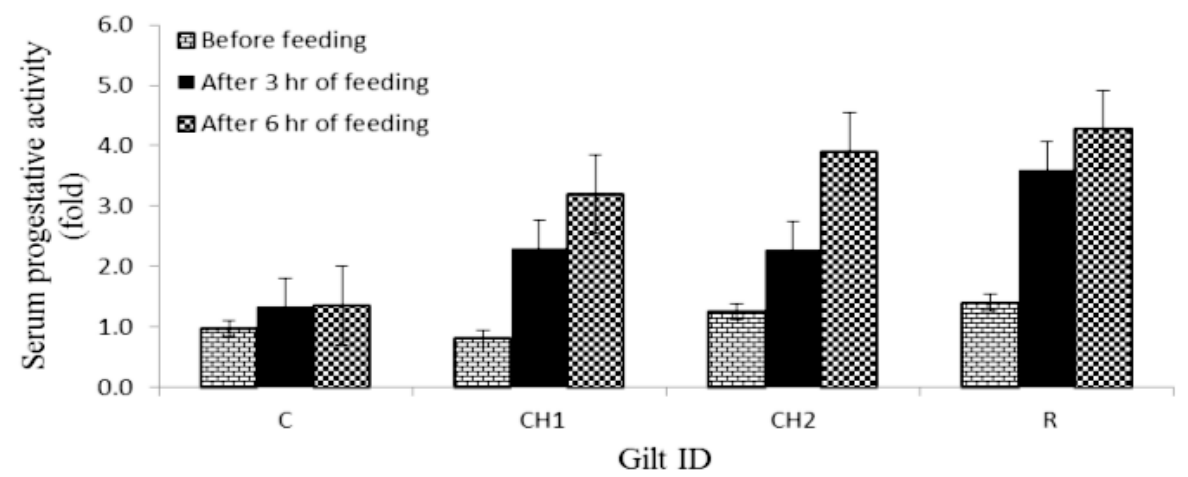

Fig. 7. Serum progestogenic activities of castrated pigs. Serum of control (C), LC extract-fed (CH1 and $\mathrm{CH} 2$ ) and altrenogest-fed (R) pigs. Data were presented as the mean fold induction compared to vehicle control \pm SEM

In this study, a highly sensitive progesterone-responsive plasmid was developed to detect progesterone and its agonists and antagonists. Animal, plant and synthetic sources of progestogen were used to test the responsiveness of the plasmid. Constructed plasmid was highly responsive to progesterone (Fig. 2), pig serum (Fig. 7) and plant extract (Fig. 6). The minimal detectable level was $1 \mathrm{nM}$ progesterone. The plasmid pGL3-2PRE-TATA was sensitive enough to be used to detect the physiological status. Oestrogen, testosterone and dexamethasone did not significantly induce luciferase activity (Fig. 5). Although, all steroid hormone receptors belong to the same superfamily (Lydon et al., 1995) RU486 suppressed the progestogenic activity by blocking the binding of progesterone to its receptor (Hazra and Pore, 2001). Fig. 4 showed that RU486 suppressed $100 \mu \mathrm{M}$ progesterone-induced luciferase activities. The developed plasmid was also responsive to anti-progesterone. T47D, a human breast cancer cell line was chosen because it naturally expresses both 
progesterone receptors A and B. Progesterone and its agonists and antagonists bind to nuclear progesterone receptor (Lydon et al., 1995) to form receptor-ligand complex, which binds to progesterone response elements on pGL3-2PRE-TATA plasmid to induce luciferase expression.

As a practical validation of plasmid, ethanolic extracts of LC and progestogen and sera from castrated pigs fed LC extract were used. LC contains dimeric phytoprogestogens, such as 3, 8-dihydro-diligustilide and Riligustilide (Lim et al., 2006a). Ethanolic extract of LC induced progestogenic activity in a dose-dependant and biphasic manner (Fig. 6). The plasmid can, therefore, be used to screen plants for progestogenic and anti-progestogenic activity. Serum progestogenic activities were significantly higher in castrated pigs after feeding altrenogest and LC extract (Fig. 7). Similar result was reported by Lim et al. (2006b) who found the serum progestogenic activity was significantly elevated after oral administration of LC extract in rats. This result indicates that exogenous progestogen can be monitored with the plasmid.

\section{Conclusions}

It is concluded that the plasmid pGL3-2PRE-TATA can be used for screening progestogenic and anti-progestogenic compounds from single or mixed samples.

\section{References}

Andersen HR, Vinggaardb AM, Rasmussena TH, Gjermandsenc IM, Bonefeld-Jørgensen EC 2002: Effects of currently used pesticides in assays for estrogenicity, androgenicity, and aromatase activity in vitro. Toxicology and Applied Pharmacology $\mathbf{1 7 9}$ 1-12.

Aupperlee MD, Smith KT, Kariagina A, Haslam SZ 2005: Progesterone receptor isoforms $\mathrm{A}$ and B: temporal and spatial differences in expression during murine mammary gland development. Endocrinology 146 3577-3588.

Badr MO, Hashem MA, Gado NN 2010: Comparative biochemical studies on steroidogenic compounds in chickens. Research in Veterinary Science 89 168-173.

Baldi E, Luconi M, Muratori M, Marchiani S, Tamburrino L, Fort G 2009: Nongenomic activation of spermatozoa by steroid hormones: facts and fictions. Molecular and Cellular Endocrinology 24 39-46.

Beato M. 1989: Gene regulation by steroid hormones. Cells 56 335-344.

Chatterjee S, Kumar V, Majumder CB, Roy P 2008: Screening of some antiprogestin endocrine disruptors using recombinant yeast based in vitro bioassay. Toxicology in Vitro 22 788-798.

Graham JD, Clarke CL 1997: Physiological action of progesterone in target tissues. Endocrine Review 18 502-519.

Hazra BG, Pore VS. 2001: Mifepristone (RU-486), the recently developed antiprogesterone drug and its analogues. Journal of Indian Institute of Science 81 287-298. 
Hotchkiss AK, Rider CV, Blystone CR, Wilson VS, Hartig PC, Ankley GT, Foster PM, Gray CL, Gray LE 2009: Fifteen years after "wingspread"--environmental endocrine disrupters and human and wildlife health: Where we are today and where we need to go. Toxicological Science 105 235-259.

Iino M, Nomura T, Tamaki Y, Yamada Y, Yoneyama K, Takeuchi Y, Mori M, Asami T, Nakano T, Yokota T 2007: Progesterone: its occurrence in plants and involvement in plant growth. Phytochemistry 68 1664-1673.

Ismail AS, Ismail HM, Sallam HN, Salem M 1995: Some aspects of the use of oral contraceptives as growth-promoting agents in poultry. Eastern Mediterranean Health $\mathbf{1}$ 241-247.

Jaakkola S, Lyytinen HK, Dyba T, Ylikorkala O, Pukkala E 2011: Endometrial cancer associated with various forms of postmenopausal hormone therapy: a case control study. International Journal of Cancer 1 1644-1651.

Jang S, Yi LS 2005: Identification of a $71 \mathrm{kDa}$ protein as a putative non-genomic membrane progesterone receptor in boar spermatozoa. Journal of Endocrinology 184 417-25.

Kuhl H, Wiegratz I 2005: Progestogen therapies: differentness in clinical effects? Trends Endocrinology \& Metabolism 15 277-285.

Lessey BA 2003: Two pathways of progesterone action in the human endometrium: implications for implantation and contraception. Steroid 68 809-815.

Lim LS, Shen P, Gong YH, Yong EL 2006a: Dimeric progestins from rhizomes of Ligusticum chuanxiong. Phytochemistry 67 728-734.

Lim LS, Shen P, Gong YH, Lee LS, Yong EL 2006b: Dynamics of progestogenic activity in serum following administration of Ligusticum chuanxiong. Life Science 79 1274-1280.

Luconi M, Bonaccorsi L, Maggi M, Pecchioli P, Krausz C, Forti G, Baldi E 1998: Identification and characterization of functional non-genomic progesterone receptors on human sperm membrane. The Journal of Clinical Endocrinology and Metabolism 83 877-885.

Lydon JP, DeMayo FJ, Funk CR, Mani SK, Hughes AR, Montgomery C A, Shyamala G, Conneely OM, O'Malley B W 1995: Mice lacking progesterone receptor exhibit pleiotropic reproductive abnormalities. Gene \& Development 9 2266-2278.

McPhail MK 1934: The assay of progestin. Journal of Physiology 83 145-156.

Mulac-Jericevic B, Lydon JP, DeMayo FJ, Conneely OM 2003: Defective mammary gland morphogenesis in mice lacking the progesterone receptor B isoform. Proceedings of the National Academy of Science 100 9744-9749.

NIH (United States National Institutes of Health) Clinical Center (2011-12-15). "Progesterone Historical Reference Ranges". (http://cclnprod.cc.nih.gov/dlm/ testguide.nsf/Index/CB26894E1EB28DEF85256BA5005B000E?OpenDocument). Retrieved. 2011-12-15.

Osinubi AA, Saalu LC 2009: Review: Environmental endocrine disruptors of testicular function. American Journal of Endocrinology and Metabolism 8 13-23. 
Schoonen WG, Dijkema R, de Ries RJ, Wagenaars JL, Joosten JW, de Gooyer ME, Deckers GH, Kloosterboer HJ 1998: Human progesterone receptor A and B isoforms in CHO cells. II. Comparison of binding, transactivation and $\mathrm{ED}_{50}$ values of several synthetic antiprogestagens in vitro in $\mathrm{CHO}$ and MCF-7 cells and in vivo in rabbits and rats. The Journal of Steroid Biochemistry and Molecular Biology 64 157-170.

Schumacher M, Hussain R, Gago N, Oudinet JP, Mattern C, Ghoumari AM 2012: Progesterone synthesis in the nervous system: implications for myelination and myelin repair. The journal of Neuroscience 6 1-22.

Sharpe RM 2001: Hormones and testis development and the possible adverse effects of environmental chemicals. Toxicology Letters 120 221-232.

Sitruk-Ware R 2004: Pharmacological profile of progestins. Maturities 47 277-283.

Smith CL, O'Malley BV 2004: Co-regulator function: a key to understanding tissue specificity of selective receptor modulators. Endocrine Review 25 45-71.

Spitz IM, Chwalisz K 2000: Progesterone receptor modulators and progesterone antagonists in women's health. Steroid 65 807-815.

Stanczyk FZ 2003: All progestins are not created equal. Steroid 68 879-890

Uthairatanakij A, Teixeira da Silva JA, Obsuwan K 2007: Chitosan for improving orchid production and quality. Orchid biotechnology 1 1-5.

Vos JG, Dybing E, Greim HA, Ladefoged O, Lambré C, Tarazona JV, Brand TI, Vethaak AD 2000: Health effects of endocrine-disrupting chemicals on wildlife, with special reference to the European situation. Critical Reviews in Toxicology 30 71-133. 